\title{
Evaluation of Performance and Emission Characteristics of Diesel Engine Fuelled with Garcinia Gummi Gutta Biodiesel and Diethyl Ether Blends
}

\author{
B. S. Ajith ${ }^{1}$, M. C. Math ${ }^{2}$, G. C. Manjunath Patel ${ }^{3^{*}}$
}

\begin{abstract}
${ }^{1}$ Department of Mechanical Engineering, Sahyadri College of Engineering and Management, Mangaluru, Affiliated to Visveswaraya Technological University, Belagavi, INDIA

${ }^{2}$ Department of Thermal Power Engineering, VTU PG Studies, Mysuru, Affiliated to Visveswaraya Technological University, Belagavi, INDIA

${ }^{3}$ Department of Mechanical Engineering, PES Institute of Technology and Management, Shivamogga, Affiliated to Visveswaraya Technological University, Belagavi, INDIA

*Corresponding Author: manju09mpm05@gmail.com
\end{abstract}

Citation: Ajith, B. S., Math, M. C. and Manjunath Patel, G. C. (2020). Evaluation of Performance and Emission Characteristics of Diesel Engine Fuelled with Garcinia Gummi Gutta Biodiesel and Diethyl Ether Blends. European Journal of Sustainable Development Research, 4(4), em0134. https://doi.org/10.29333/ejosdr/8353

ARTICLE INFO
Received: 26 Apr. 2020
Accepted: 11 Jun. 2020

\begin{abstract}
The novel garcinia gummi-gutta seed is used for extraction of biodiesel using transesterification process. The impact of diethyl ether (DEE) in biodiesel on the fuel properties was examined. The performance and emission characteristics of six fuels (B20DEE10, B30DEE10, B40DEE10, B100, B100DEE10 and D100) are tested on diesel engine from no-load to full load conditions. The addition of $10 \%$ diethyl ether to $20 \%$ biodiesel (B20) closely resemble the fuel properties of diesel fuel (D100) compared to other tested biodiesel blends. The performance parameters (brake specific fuel consumption (BSFC) and brake thermal efficiency (BTE)) and emission characteristics (carbon monoxide (CO), nitrous oxide (NOx) and hydrocarbon (HC)) are examined for six fuels at different engine load conditions. BSFC of all biodiesel showed comparatively higher value to that of diesel fuel at all engine loading conditions. BTE of diesel fuel showed higher values compared to other biofuels. Biodiesel blends resulted in reduced carbon monoxide and hydrocarbon emissions compared to diesel fuel. NOx emissions are higher for biodiesel and its blends compared to diesel fuel at all loads. Addition of $10 \%$ diethyl ether to biodiesel (B100) fuel resulted in better performance and emission characteristics compared to B100 fuel tested at full load engine conditions.
\end{abstract}

Keywords: Garcinia Gummi-gutta Seed, DEE, BSFC, BTE, HC, CO, NOx

\section{NOMENCLATURE}

$\begin{array}{ll}\text { BSFC } & : \text { Brake Specific Fuel Consumption } \\ \text { BTE } & : \text { Brake Thermal Efficiency } \\ \text { B100 } & : 100 \% \text { biodiesel } \\ \text { B20DEE10 } & : 20 \% \text { biodiesel+ } 10 \% \text { diethyl ether }+70 \% \text { diesel ( } \% \text { by volume) } \\ \text { B30DEE10 } & : 30 \% \text { biodiesel+ } 10 \% \text { diethyl ether }+60 \% \text { diesel (\% by volume) } \\ \text { B40DEE10 } & : 40 \% \text { biodiesel }+10 \% \text { diethyl ether }+50 \% \text { diesel (\% by volume) } \\ \text { B100DEE10 } & : 100 \% \text { biodiesel+10\% diethyl ether (\% by volume) } \\ \text { CO } & : \text { Carbon monoxide } \\ \text { CSt } & : \text { centistokes } \\ \text { CO } & : \text { Carbon dioxide } \\ \text { DEE } & : \text { diethyl ether } \\ \text { D100 } & : 100 \% \text { diethyl ether } \\ \text { GGG } & : \text { Garcinia gummi-gutta } \\ \text { HC } & : \text { Hydrocarbon } \\ \text { Ppm } & : \text { parts per million } \\ \text { NOx } & : \text { Oxides of nitrogen or nitrous oxide }\end{array}$




\section{INTRODUCTION}

In today's $21^{\text {st }}$ century, energy sector (i.e. crude oil exporter) contributions are playing a major role in deciding the economic growth of many countries. The depletion of fossil fuels, air pollution and stringent environment laws limit the use of conventional energy sources (Chourasia et al., 2018). Globally 11 billion tons of fossil fuels are consumed every year, which accounts to $82.67 \%$ of energy consumed from the fossil fuels (Nanthagopal et al., 2019). This raise major problem to compensate the huge energy demand for industrialization, modernization of human welfare and societal development (Sahoo et al., 2009). In India, over 10 million diesel engines run for the purpose of transportation and farming activities (Agarwal et al., 2003). Thereby, stringent demand still exists for alternate fuels which can run on the existing diesel engines without major modifications (Patel et al., 2017). Researchers used the modified fuels to run the existing diesel engines without any hardware modifications (Devarajan et al., 2018; Rathinam et al., 2018). Non-edible oils namely Linseed, Karanja, Neem, Palash and Kusum can be used with different blends that closely resembles neat diesel fuel characteristics (Gui et al., 2008). Although vegetable oils and their blends with diesel fuel resulted in approximately similar combustion characteristics, but are not been recommended for long term engine run efficiently (Agarwal et al., 2003). This might be due to the poor fuel atomization, ring sticking, injector problems (i.e. choking), carbon deposits on pistons, pump failure) and lube oil dilution by crank-case polymerization (Agarwal, 2005). In addition, the cost of raw material (vegetable oils) poses economic problems (Hingu et al., 2010). In view of the above, the forest-based plant oils are recommended not only of their economic benefits, but also for higher biodiesel production.

Forest-based bioenergy (forest plant derived oils) is gaining significant attention over food crop-based energy production due to their multiple benefits (Agarwal et al., 2003). Increased population led to shortage of food grains for daily consumptions. Many countries are diverting their food crops (primarily used for food supply, animal feed) to energy production to compensate the huge energy demand (Somerville et al., 2010). The competitive use of agriculture lands for energy production led to reduced biodiversity by $60 \%$ with corn and soybean fields in US, and $85 \%$ in palm plantations in Southeast Asia compared to unconverted habitats (Fargione et al., 2010). India imports over four million tonnes of vegetable oils during 2008-2009, and diversion of crop land for energy production is not practically advisable (Bora and Baruah, 2012). Study also reported that transforming the rainforests, peat and grasslands to crop-based energy production (biodiesel) leads to more emissions and water pollution in US, Southeast Asia and Brazil (Fargione et al., 2008; Richard, 2010). In India, shortage of food grains and agriculture lands to meet the daily consumption requirements (food) of increased population limit the use of crop-based energy production (Kumar and Sharma, 2011). In India, forest-based bioenergy productions are at development stage due to unstable feedstock and suppliers, inadequate research and development.

In China, to compensate the ever-increasing energy demand, the oil-bearing seeds of trees are planted (i.e. to develop new energy forests) on land which are not suitable for crop production. There are major eight species of trees (Sapindus mukorossi Gaertn, Jatropha curcas L., Sapium sebiferum (Linn.) Roxb., Swida wilsoniana (Wanger.) Soja 'k, Vernicia fordii (Hemsl.) Airy Shaw, Xanthoceras sorbifolia Bunge, Camellia oleifera Abel., Pistacia chinensis Bunge) planted to develop ever-green forests which can be commercialized for energy productions (Yang et al., 2013). The significant advantage of forest-based oil-bearing plant species are adaptability to unstable climatic condition, high oil yield content, and long harvest period (Shao and Chu, 2008). In India, research work is carried out on few species of forest-based trees (Pongamia, Terminalia belerica Robx, soapnut, Jatropha curcas, Karanja, koroch, neem, mahua, polanga, rubber, jojoba) (Banapurmath et al., 2008; Chakraborty et al., 2009; Dwivedi and Sharma, 2014; Ghadge and Raheman, 2005; Kumar and Sharma, 2011; Ramadhas et al., 2005; Sahoo et al., 2007, 2009) for biodiesel production. Indian forests trees are getting significant research attention from past two decades, however their efforts to large scale biodiesel production through commercial routes still require intense studies. The choice of biodiesel feedstock depends largely by geographical location (i.e. region specific) and available resources. Furthermore, government must promote appropriate tree species based on region specific as low-cost feedstock for biodiesel production that address several socioeconomic issues.

Garcinia gummi-gutta (GGG) is a forest-based tree of Guttiferae family species which are locally available at Balehonnur village of Karnataka, India. GGG tress grow largely in coastal and western Ghats of India. The oils are derived from the non-food grain seeds of garcinia gummi-gutta tree. GGG is a miscellaneous stray spice tree due to the following: a) fruit contains higher percent of vitamin C and hydroxy citric acid which helps in natural weight loss and cure heart disease (Duke, 2002; Semwal et al., 2015). b) fruit rind helps in preparing food curries and garnish. c) leaves of tree helps to improve the soil fertility. d) extracted resin from the tree possess high medicinal value (to cure tumor, ulcers, parasites, fever, and so on) (Jena et al., 2002). The tree provides necessary shade to commercial plants (coffee, pepper, and so on) and their hard wood timber (age of 20-30 years) could be used for construction and making furniture (Orwa et al., 2009). GGG based by-products such as seed cake can be used for preparing bio composites and glycerol used as humectant in sweets, cakes, meats and cheeses, as a solvent for beverages and food by offering flavour and colours (Monteiro et al., 2018). Further, glycerol is used as raw material for preparing soap, tooth pastes, textile, leather, cosmetics, plastics, synthetic resins, explosives and pharmaceutical industries (Ong et al., 1991). Not much research efforts made on garcinia gummi-gutta seed oil for biodiesel production for practical usage and commercialization for large scale production.

Neat oil derived from feedstocks (i.e. seeds or vegetables or animal fats) possess various long-term problems (poor atomization, injector related parameters, ring sticking and so on) in diesel engines (Agarwal, 2005; Bora and Baruah, 2012; Chakraborty et al., 2009; Ramadhas et al., 2005; Sahoo et al., 2009). These problems are due to the inherent fuel properties (physical and combustion) such as low volatility, energy content and efficiency, and high viscosity, density and NOx emissions and so on (Arul Gnana Dhas et al., 2018; Devaraj et al., 2018). The use of biofuels for long-run in diesel engines may results in engine (i.e. engine parts such as cylinder liner, crankshaft, piston, pistons rings, crankshaft bearing and journals) to fail catastrophically 
Table 1. Summary of the results of experimental uncertainty and accuracy

\begin{tabular}{ccc}
\hline Variables & Accuracy & Uncertainty (\%) \\
\hline Load & $\pm 0.1 \mathrm{~kg}$ & \pm 0.34 \\
\hline Fuel flow rate & $\pm 0.03 \mathrm{l} / \mathrm{h}$ & \\
\hline Brake specific fuel consumption (BSFC) & $\pm 0.05 \mathrm{~g} / \mathrm{kW} \mathrm{h}$ & \pm 0.48 \\
\hline Brake thermal efficiency (BTE) & \pm 0.6 & \pm 0.82 \\
\hline Carbon monoxide (CO) & $\pm 0.01 \mathrm{vol} \%$ & \pm 0.75 \\
\hline Oxides of nitrogen (NOx) & $\pm 1 \mathrm{ppm}$ & \pm 1.04 \\
\hline Hydrocarbon (HC) & $\pm 1 \mathrm{ppm}$ & \pm 1.75 \\
\hline
\end{tabular}

(Chourasia et al., 2018). In view of engines to run for longer duration efficiently the fuel properties of biofuel are to be altered with certain additives (Srihari et al., 2017). Transesterification process alters the structure of fatty acid molecules of derived oils (biodiesel crude oil) to prepare desired fuel properties useful for long-run engine operation. Although transesterification process alters the biodiesel fuel properties, but they limit the biodiesel to blend less than $20 \%$ with diesel for long run engine operation. The diethyl ether (DEE) addition to biodiesel alter the fuel properties (cetane number, viscosity, oxygen and energy content), improve brake thermal efficiency and reduces emissions ( $\mathrm{CO}_{2}$ and NOx) (Das et al., 2018; Hansen et al., 2005). The diethyl ether additive possesses low flash point $\left(-40^{\circ} \mathrm{C}\right)$, and expected to have drastic reduction in the flash point with increased percent of diethyl ether additive in biodiesel (Das et al., 2018). Many research studies reported that the diethyl ether additive up to $10 \%$ to biodiesel-diesel blends showed significant improvement in combustion and emission performance characteristics in diesel engines (Ali et al., 2016; Barik et al., 2017; Das et al., 2018; Devaraj et al. 2008, 2015). From the above detailed literature, only a few works reported on biodiesel production with the forest based on non-food grain seeds as a feedstock. Further, not much work focused yet on oxygenated additive to improve the base fuel and develop ternary fuel blends that offer better engine performance and reduced emission characteristics.

Today's environmental concern, fossil fuel depletion, increased energy demand and fuel cost being the major reasons for searching alternate fuels. In the present work, forest based garcinia gummi-gutta tree seeds are used for production of biodiesel due to their feedstock availability at low-cost. In addition, the by-products of garcinia-gummi gutta seeds have many commercial usages. The crude oil obtained from garcinia gummi-gutta seeds are transesterified to alter the fuel properties close to neat diesel fuel. Ten percent of diethyl ether is added as additive to biodiesel fuel. Five blended fuels are prepared in combination of $10 \%$ DEE with different proportions of diesel and biodiesel. The prepared blended fuels are tested against the fuel properties for their practical usage. Finally, the fuels (diesel-biodiesel-diethyl ether) are tested for performance and emission characteristics at different loading conditions in diesel engine.

\section{Uncertainty and Error Analysis}

Uncertainty or error analysis use systematic method to estimate the error associated to experimental data. In addition, uncertainty analysis helps to estimate the errors associated with measurement of different parameters (refer Table 1). Holman principle is employed for conducting uncertainty and error analysis (Holman, 1996). During experimentation and response measurements there are certain factors such as selection of measuring instruments, (calibration and environment) condition, reading and observations influences the errors which results in uncertainty. Uncertainty analysis thus needed to know the accuracy of results obtained from the experiments. The resolution and ranges of different instruments used are presented in Table 1. The overall uncertainty of the present experiments is estimated according to Eq. 1.

$$
\begin{gathered}
\text { Overall uncertainity }=\sqrt{\left(\text { load }^{2}+\text { fuelflowrate }^{2}+B S F C^{2}+B T E^{2}+C O^{2}+N O_{X}^{2}+H C^{2}\right)}(1) \\
\text { Overall uncertainity }=\sqrt{\left(0.34^{2}+0.48^{2}+0.82^{2}+0.75^{2}+1.04^{2}+1.75^{2}+1.30^{2}\right)} \\
\text { Overall uncertainity }= \pm 2.72
\end{gathered}
$$

Each set of experiments are replicated thrice and the obtained overall uncertainty value was found equal to $2.72 \%$. Statistical based error analysis is conducted to know the independent variables or process significance tested for the pre-set confidence level set at $95 \%$ (i.e. $p=0.05$ ). The overall uncertainty error values from the experiments and instruments errors are found to be less than $5 \%$, which signifies the obtained experimental data is statistically significant.

\section{MATERIALS AND METHODS}

\section{Materials}

Garcinia gummi-gutta seeds are collected from the forest region of Balehonnur Village of Karnataka, India. Mechanical expeller unit is used to extract the oil from the collected seeds. Diethyl ether is purchased from Vasa Scientific Company (Bangalore, India). The diesel fuel essential to prepare the biodiesel blends are obtained from Mangalore, India.

\section{Methods}

Single stage alkaline-catalyzed transesterification process is employed for converting the Garcinia gummi-gutta seed oil (crude oil) to biodiesel. Transesterification process is carried out by using magnetic stirrer equipped hot plate, one litre three neck 
Table 2. The optimal values of transesterification parameters and biodiesel yield

\begin{tabular}{cc}
\hline Transesterification factors & Optimal value \\
\hline Methanol $(\mathrm{v} / \mathrm{v}), \%$ & 40.0 \\
\hline Sodium hydroxide, g/100cC & 0.83 \\
\hline Reaction time, $\min$ & 60.0 \\
\hline Reaction temperature, ${ }^{\circ} \mathrm{C}$ & 60.0 \\
\hline
\end{tabular}

Table 3. Properties of blending stocks

\begin{tabular}{|c|c|c|c|c|}
\hline Properties & $\begin{array}{r}\text { Diesel } \\
\text { (D100) }\end{array}$ & Diethyl ether & $\begin{array}{c}\text { Garcinia gummi-gutta } \\
\text { oil }\end{array}$ & Biodiesel (B100) \\
\hline Density, $\mathrm{kg} / \mathrm{m}^{3}$ & 800 & 720 & 850 & 820 \\
\hline Calorific value, $\mathrm{MJ} / \mathrm{kg}$ & 44.8 & 36.8 & 38.2 & 40.1 \\
\hline Kinematic viscosity at $40^{\circ} \mathrm{C}$ (cSt) & 4.10 & $\begin{array}{ll}--- \\
-1\end{array}$ & 6.84 & 4.83 \\
\hline Flash point, ${ }^{\circ} \mathrm{C}$ & 60.0 & -40 & 220 & 185 \\
\hline Fire point, ${ }^{\circ} \mathrm{C}$ & 69.0 & --- & 230 & 192 \\
\hline
\end{tabular}

Table 4. Fuel properties of biodiesel-diesel blends

\begin{tabular}{|c|c|c|c|c|c|c|}
\hline Property & D100 & B20DEE10 & B30DEE10 & B40DEE10 & B100DEE10 & B100 \\
\hline Kinematic Viscosity at $40^{\circ} \mathrm{C}$ (cSt) & 4.1 & 4.16 & 4.21 & 4.24 & 4.76 & 4.83 \\
\hline Density, $\mathrm{kg} / \mathrm{m}^{3}$ & 800 & 803 & 805 & 806 & 816 & 820 \\
\hline Flash point, ${ }^{\circ} \mathrm{C}$ & 60 & 74.6 & 87.6 & 95.2 & 145 & 185 \\
\hline Fire point, ${ }^{\circ} \mathrm{C}$ & 69 & 89.6 & 102.8 & 109.3 & 150 & 192 \\
\hline Higher calorific value, $\mathrm{MJ} / \mathrm{Kg}$ & 44.8 & 43.4 & 42.9 & 42.10 & 40.8 & 40.1 \\
\hline
\end{tabular}

bottomed flask and reflux condenser. The crude oil extracted from mechanical expeller is heated to $80^{\circ} \mathrm{C}$ to remove the presence of water (if any). The measured quantity of garcinia gummi-gutta oil is taken on a flask and stirred continuously when placed on a hot plate subjected to a temperature of $55^{\circ} \mathrm{C}$. This method removes the presence of solid particles (if found any). The obtained oil is mixed with $50 \%$ sodium methoxide solution and stirred continuously for 10 mins. Later, the remaining $50 \%$ sodium methoxide solution is added to the prepared solution and stirred continuously for about 20 minutes. The solution is then heated to a temperature of $60^{\circ} \mathrm{C}$ for the predefined reaction time (i.e. $60 \mathrm{mins}$ ). Later, two phase solution (upper layer: methyl ester and bottom layer: glycerin) is obtained when the solution is cooled at an ambient temperature for about 8 hrs. Centrifugation process remove the traces of catalyst (present, if any) and sedimentation process separate the methyl ester. Glycerin is the by-product obtained along with Garcinia gummi-gutta methyl ester. Experiments are carried out with different combination and levels of transesterification parameters to obtain the maximum yield. The optimized parameters resulted to a maximum biodiesel yield of 96.2\% is presented in Table 2.

\section{Fuel Properties}

The basic properties of the blending stocks (Diesel, Garcinia gummi-gutta crude oil, Diethyl ether) are presented in Table 3. The fuel properties of three ternary (diesel-biodiesel-diethyl ether) blends prepared with different proportions are compared with neat diesel (D100) and biodiesel (B100) fuel. The fuel blends are prepared based on volume basis on a magnetic stirrer carried out at room temperature. Three type of biodiesel blended fuels are prepared for the present work such as B20DEE10 (20\% of biodiesel and $10 \%$ of diethyl ether), B30DEE10 (30\% of biodiesel and $10 \%$ of diethyl ether), B40DEE10 ( $40 \%$ of biodiesel and $10 \%$ of diethyl ether) and B100DEE10 (100\% of biodiesel and 10\% of diethyl ether). The blended fuels are tested for the presence of settling characteristics at room temperature for about 3 days (72 hours). However, there is no presence of settling of fuels are observed. Thereafter, the fuels (B20DEE10, B30DEE10, B40DEE10, B100DEE100, B100, and D100) are tested for their properties and practical utility in engines. Table 3 show the properties of different fuels.

Table 3 show the experimental values of the properties (density, calorific value, viscosity, flash and fire point) of different fuels (diesel, diethyl ether, garcinia gummi-gutta crude oil and biodiesel). The viscosity of garcinia gummi-gutta crude oil (i.e. before subjected to transesterification process) is higher than that of B100 (100\% biodiesel) and diesel (refer Table 3). The biodiesel possesses higher viscosity due to their high saturation level and oxygen content. Garcinia gummi-gutta crude oil possess higher kinematic viscosity of $6.84 \mathrm{cSt}$, which was reduced to $4.83 \mathrm{cSt}$ after undergoing transesterification process. It was also observed that addition of $10 \%$ diethyl ether reduces the viscosity of biodiesel (B100) by $1.45 \%$ (refer Table 4). The viscosity of the blended fuels also reduces with the addition of diethyl ether, as their kinematic viscosity possess comparatively lower value to that of diesel and biodiesel (refer Table 4). The densities of biodiesel and diesel fuels are different, highest being the biodiesel (B100) by $2.5 \%$ than diesel fuel (refer Table 4). The densities of different blended fuels (biodiesel and diesel) can be reduced with the addition of diethyl ether, due to their lower density value (720 cSt) (refer Tables 3 and 4). Calorific value of biodiesel (B100) fuel is lower by $10.49 \%$ to that of diesel, and biodiesel with diethyl ether (B100DEE) by $8.93 \%$ to that of diesel fuel (refer Table 4). The biodiesel possesses higher flash and fire point than diesel (refer Table 4), and additive diethyl ether could reduce the flash and fire points that could suits well to store, handle and transport safely (refer Table 4). Noteworthy that, the diethyl ether had remarkably very low flash point than diesel. 
Table 5. Engine Specification

\begin{tabular}{cc}
\hline Make & Kirloskar (India) \\
\hline Engine model & TV1 \\
\hline Type & Four stroke, Direct injection, Variable compression ratio \\
\hline Number of cylinders & One \\
\hline Bore x stroke $(\mathrm{mm})$ & $87.5 \times 110$ \\
\hline Rated output $(\mathrm{kw})$ & 5.2 \\
\hline Compression ratio & $17.5: 1$ \\
\hline Rated speed $(\mathrm{rpm})$ & 1500 \\
\hline Cooling mode & Water-cooled
\end{tabular}

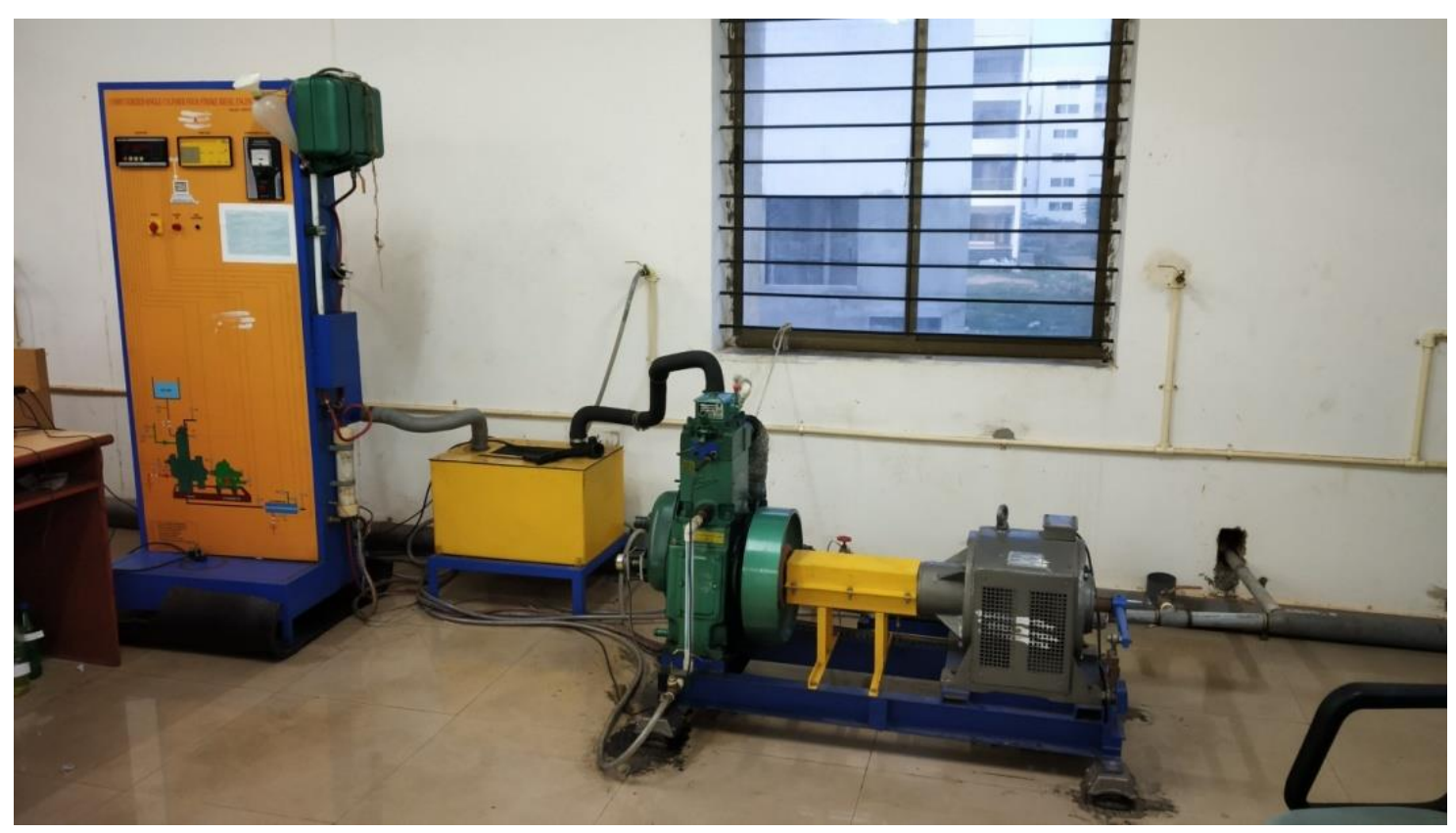

Figure 1. Experimental set-up of computerized diesel engine test rig

\section{Experimental Procedure and Engine specification}

The experiments are conducted to know the performance and emission characteristics of six fuels tested on a direct injected Kirloskar TV1 single cylinder, naturally aspirated, four stroke based water-cooled diesel engine. The specification of test engine is presented in Table 5. The extraction of the parent oil from the garcinia gummi-gutta seeds is carried out by using mechanical expeller. The extracted oil is later converted into biodiesel and the basic fuel properties are tested in the laboratory (refer Tables 3 and 4). The engine was loaded with eddy current dynamometer. This engine has its ability to operate with a maximum rated power of $5.2 \mathrm{KW}$, with a speed maintained constant at $1500 \mathrm{rpm}$. Eddy current dynamometer with electromagnetic force help the engine to operate at variable loading conditions. Temperatures are measured by mounting sensors at an appropriate location. The engine jacket water and cooling water flow rates are measured with the help of rotameter. Calibrated burette (volumetric) and stop watch helps to measure accurately the flow rate of fuel consumption. Exhaust gasses (i.e. CO, HC and NOx) were measured by equipping ECM1601 model Gas Analyzer. The entire system was connected to a computer to receive the signals. The experimental set-up used for the present work is shown in Figure 1.

During experimentation the five incremental steps of $20 \%$ are varied with respect to the engine loads varied between the ranges from no-load to full load (i.e. $0 \%, 20 \%, 40 \%, 60 \%, 80 \%$ and $100 \%$ ) conditions. The performance and emission (BSFC, BTE, NOx, CO, and HC) characteristics of six fuels (B20DEE10, B30DEE10, B40DEE10, B100, B100DEE10 and D100) at each engine load conditions are examined. The fuel flow rate to the engine is adjusted manually viz. fuelling rack of fuel injection pump to operate at a constant speed of $1500 \mathrm{rpm}$. The engine was said to operate according to the catalogue values prior to experimentation and record the responses (BSFC, BTE, NOx, $\mathrm{CO}$ and $\mathrm{HC}$ ). Fuel tank and fuel injection systems are cleaned after ensuring the complete fuel burnout which was left out (if any) from the previous experiments. The same procedure is employed while introducing the new fuel to an engine. Prior to introducing the new fuel to an engine, engine starts initially with neat diesel fuel and allowed to warm-up continuously for about 30 minutes till it attain the steady state condition. The performance and emission characteristics of all six fuels are tested at different (0-100\%) engine loading conditions.

\section{RESULT AND DISCUSSION}

Performance (BSFC and BTE) and emission characteristics (CO, NOx and $\mathrm{HC}$ ) tested at different engine load conditions and fuels are discussed below. 


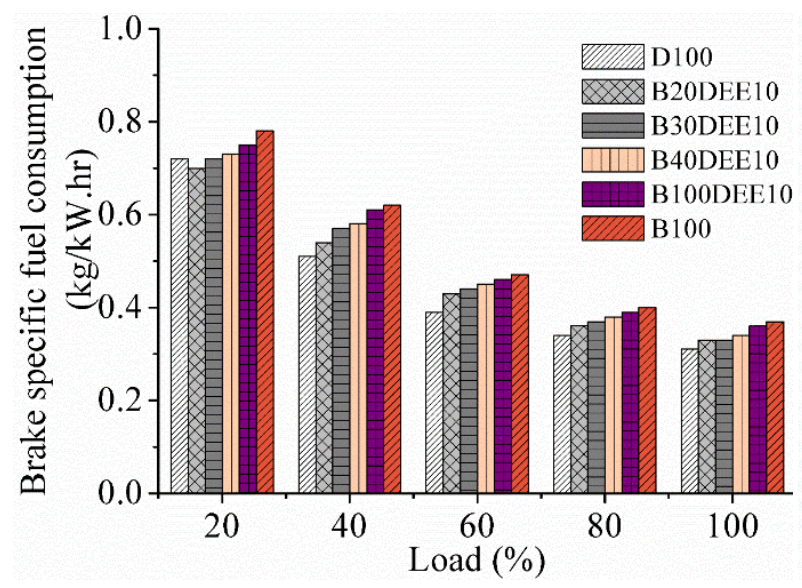

(a)

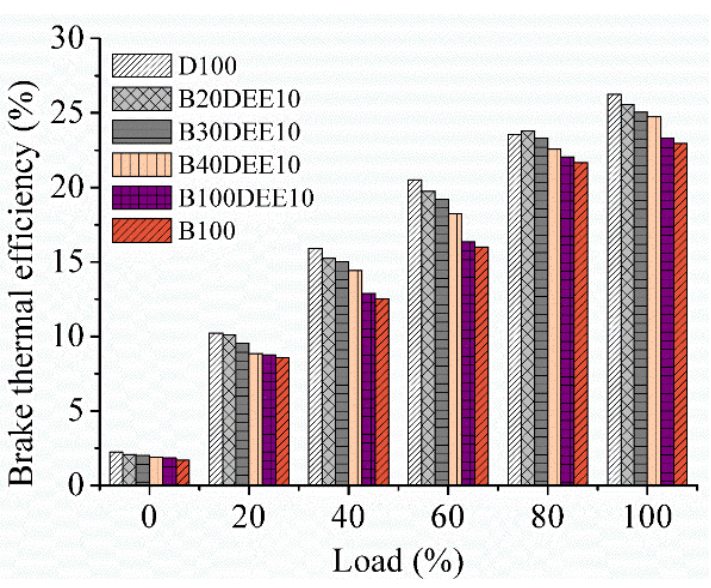

(b)

Figure 2. Performance variations with different fuels tested at different engine load: a) BSFC, and b) BTE

\section{Brake Specific Fuel Consumption}

Figure $2 \mathrm{a}$ show the variation in brake specific fuel consumption of test fuels at different engine loading conditions. The fuel efficiency (ratio of rate of fuel consumed to the power developed) of engines is measured with the help of brake specific fuel consumption. The BSFC of all the biodiesel blended fuels showed significantly higher (except B20DEE10) value to that of the diesel fuel (refer Figure 2a). BSFC decreases with the increased application of load may be due to the generated higher brake power compared to the fuel consumed. Increased percent of biodiesel in the prepared blends resulted in increased fuel consumption for all the engine loads (20\%-100\%). This occurs due to the combined effect of physical and chemical properties (i.e. density, viscosity and calorific value) of a fuel. It is also true that the biodiesel possesses lower calorific value than the diesel fuel, and therefore consumes more fuel to generate the same power output. Higher fuel consumption with increased percent of biodiesel is attributed to the combined effect of constant fuel injection rate and high viscosity in biodiesel blends. Table 4 showed that the viscosity tends to increase with the increased proportion of biodiesel in the prepared blends. At full load condition the brake specific fuel consumption of B20DEE10, B30DEE10, B30DEE10, B40DEE10, B100DEE10, and B100 is 6.45\%, 6.45\%, 9.68\%, $16.13 \%$ and $19.36 \%$ higher than neat diesel (D100) fuel. Important to note that, addition of diethyl ether by $10 \%$ reduces the brake specific fuel consumption of $2.78 \%$ for B100 fuel tested under full engine loading condition. The physical and chemical properties of biodiesel change the combustion and injection timing are the probable reasons for higher BSFC of biodiesel than the diesel fuel (refer Table 4). The fuel properties such as density and viscosity decreases with the addition of $10 \%$ diethyl ether (i.e. B100DEE10) to biodiesel (B100) which facilitates better atomization in combustion chamber that resulted in $2.78 \%$ decrease in BSFC (refer Figure 2a). The fuel properties of different biodiesel blends are presented in Table 4.

\section{Brake Thermal Efficiency}

Figure $\mathbf{2} \mathbf{b}$ show the variation in brake thermal efficiency with the engine load. The practical significance in measuring the brake thermal efficiency (ratio of useful output of a device to the input energy terms) is to know the how best the energy transfer or conversion is taking place. The BTE increases with increased percent of engine load for all tested fuels (refer Figure $\mathbf{2 b}$ ). This occur due to the following reasons, 1) increased power developed and heat loss reduction, and 2) difference in physical and chemical properties of the test fuels (refer Table 4). The test fuel properties could significantly alter the brake thermal efficiency of an engine, which helps to gain better fuel combustion and reduced emissions. At full load engine condition running at $1500 \mathrm{rpm}$, BTE was 26.25\% for D100, 25.58\% for B20DEE10, 25.03\% for B30DEE10, 24.74\% for B40DEE10, 22.97\% for B100 and 23.29\% for B100DEE10, respectively (refer Figure $\mathbf{2 b}$ ). At full load conditions the BTE decreases with increased percent of biodiesel in the prepared blends might be due to the reduction in calorific value (refer Table 4). Addition of $10 \%$ diethyl ether to B100 fuel, resulted in improved engine brake thermal efficiency of a fuel (i.e. B100DEE10) by $1.4 \%$. The presence of diethyl ether in biodiesel alters the chemical composition, improves volatility and flash point which favor the combustion phenomenon resulted in better thermal efficiency (Tables 3 and 4). In addition, higher viscosity of biodiesel (B100) is reduced with 10\% DEE addition. High volatility and low kinematic viscosity characteristics help in improving atomization and spray characteristics (i.e. breaking the biodiesel to fine droplets) during the injection process resulted in improved brake thermal efficiency by $1.4 \%$ at full load condition. Note that, BTE of all the biodiesel blends are lower than the diesel fuel might be due to the following, poor volatility and atomization, incomplete combustion (due to insufficient air), low calorific or heating value, high density and viscosity.

\section{Carbon Monoxide Emission}

Figure 3a show the variations of carbon monoxide emission for different fuels tested at different engine load condition. Toxic gases in the form of carbon monoxide emissions evolved during the combustion process are due to lack of oxygen content as a result of poor air entrainment, mixing and combustion process. For all the biodiesel blended fuels the carbon monoxide emissions are comparatively lesser than that of diesel fuel at all engine loading conditions (0-100\%). At full engine load, compared to diesel fuel the carbon monoxide emission is lesser by 13.95\% for B20DEE10, 16.28\% for B30DEE10 and B40DEE10, 20.93\% for B100 and $30.23 \%$ for B100DEE10, respectively. The reason for less carbon emission by the biodiesel fuels are due to inherent oxygen content, 


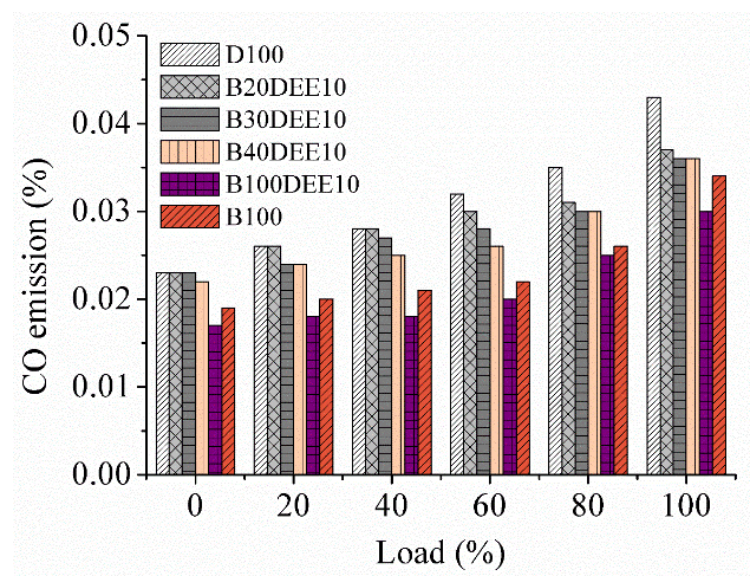

(a)

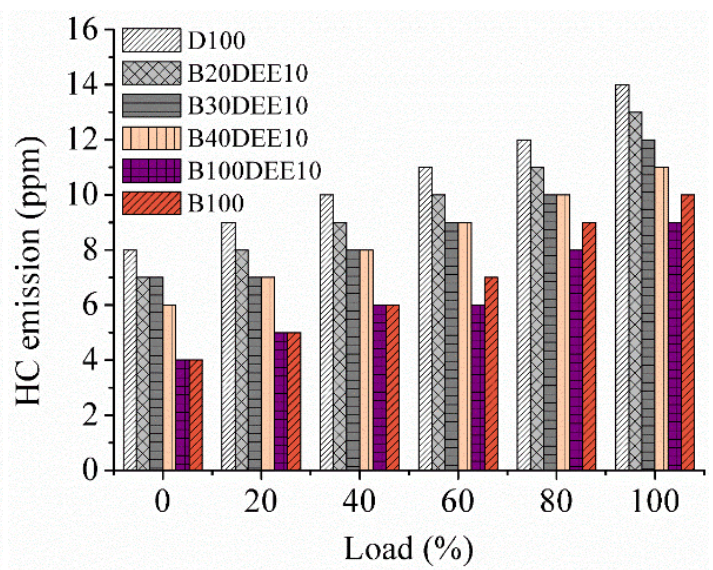

(b)

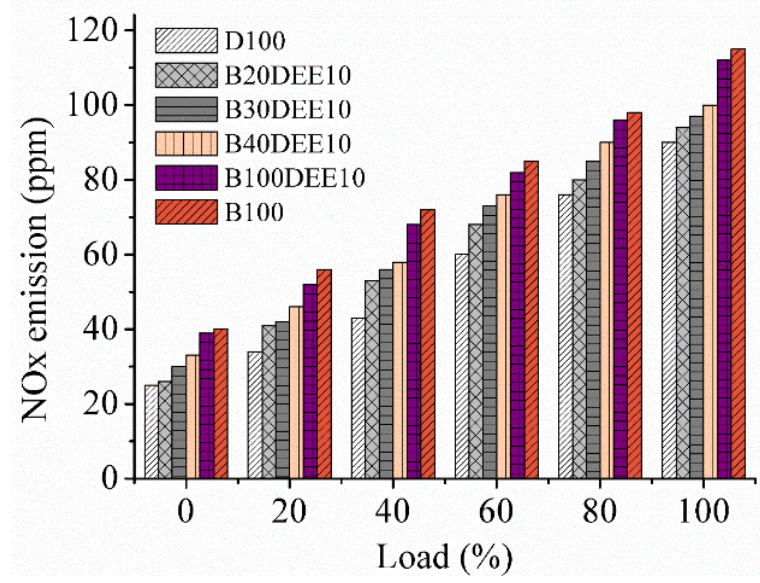

(c)

Figure 3. Emission variations with different fuels tested at different engine load: a) CO emission, b) HC emission, and c) NOx emission

low ignition delay time period and improved spray atomization that supports better combustion. High volatility and low kinematic viscosity of diethyl ether addition of $10 \%$ to B100 (at full load condition) could not only improve the combustion performance but also reduces the carbon monoxide emission by $11.75 \%$.

\section{Hydrocarbon Emission}

Figure $\mathbf{3 b}$ show the hydrocarbon emission variations of six fuels tested with different engine loading conditions. $\mathrm{HC}$ emission increases with increase in engine load spectrum for all fuels. At full load condition, $\mathrm{HC}$ emissions of biodiesel blended fuels namely B20DEE10, B30DEE10, B40DEE10, B100DEE10 and B100 are lesser by $7.14 \%, 14.29 \%, 21.43 \%, 35.71 \%$ and $28.57 \%$ to that of diesel fuel. Addition of $10 \%$ diethyl ether to B100 fuel significantly reduces the hydrocarbon emission by $10 \%$. DEE additive helps in automatic ignition of fuel-air mixture that offer sufficient time for complete combustion which helps to decrease the hydrocarbon emission compared to neat biodiesel. The reason for less hydrocarbon emissions by biodiesel compared to diesel fuel might be due to the presence of rich oxygen content, higher gas temperature as a result of reduced condensation hydrocarbons in a fuel.

\section{Oxides of Nitrogen Emission}

Oxides of nitrogen evolved after undergoing the reaction of nitrogen and oxygen at elevated temperatures (i.e. adiabatic flame temperature related to peak cylinder temperature). NO is a primary constituent element results in nitrous oxide emissions (NOx). Figure 3c show the NOx emissions of D100, B20DEE10, B30DEE10, B40DEE10, B100, and B100DEE with the load variations (0$100 \%)$. It was observed that increase in percent of load tends to increase the NOx emission for all fuels. Furthermore, NOx emissions are comparatively higher for biodiesel than neat diesel fuel at all loads. NOx emission (ppm) values correspond to minimum and maximum load were found equal to 25 and 90 for D100, 26 and 94 for B20DEE10, 30 and 97 for B30DEE10, 33 and 100 for B40DEE10, 39 and 112 for B100DEE10, and 40 and 115 for B100 fuels. At full load condition the addition of diethyl ether by $10 \%$ to B100 fuel could reduce the nitrous oxide emission by $2.61 \%$. The DEE reduces the NOx are due to high latent heat evaporation results in complete combustion at low temperatures. Higher NOx values at maximum loading conditions are primarily due to the more fuel burnt which offers better combustion characteristics (i.e. exhaust gas temperature) leads to increased engine cylinder temperature that results in higher NOx emissions. Note that nitrogen remains inert up to certain temperature, latter it reacts with oxygen to form oxides of nitrogen. Furthermore, higher NOx emission with biodiesel compared to diesel fuel are due to the following, higher cylinder temperature and peak pressure, and excess amount of oxygen. 


\section{CONCLUSION}

The following conclusions are drawn for the present research work,

1. The biodiesel-diesel-diethyl ether blended fuels are tested for fuel properties and their performance and emission characteristics at different loading conditions and compared with neat diesel and biodiesel fuels. Increase in biodiesel content could results in increase in density, viscosity, flash and fire points, whereas reverse trend was observed with decrease in calorific values.

2. BSFC had shown significantly higher value for all biodiesel blends (except B20DEE10 for $20 \%$ load) compared to diesel fuel at all engine loads. At full load engine condition, the addition of $10 \%$ DEE for B100 fuel results in $2.78 \%$ reduction in BSFC. High BSFC for biodiesel fuel compared to diesel fuel are due to difference in fuel properties (physical and chemical) and resulted change in combustion and ignition timings.

3. BTE increases with increased percent of engine load for all six fuels. Improved brake thermal efficiency is due to the difference in physical and chemical properties, improved power developed as a result of reduced heat loss. BTE improves with the addition of $10 \%$ DEE to B100 fuel by $1.4 \%$ at full load condition. DEE alters the chemical composition of biodiesel due to their high volatility and lower kinematic viscosity flash point which offers better combustion characteristics that results in better brake thermal efficiency.

4. Biodiesel offer less carbon monoxide emission than diesel fuel, might be due to the inherent oxygen content, low ignition delay time and improved spray atomization which offer better combustion. DEE addition to B100 fuel, reduces the carbon monoxide emission by $11.75 \%$ at full load engine condition.

5. HC emission increases with increase in engine load spectrum for all fuels. Compared to diesel fuel the biodiesel and its blends showed reduced hydrocarbon emissions. 10\% DEE addition to B100 fuel reduces the hydrocarbon emission at full load engine conditions.

6. NOx emissions are lesser for biodiesel compared to neat diesel fuels at all engine loads. $2.61 \%$ reduction of nitrous oxide was observed with $10 \%$ DEE additive to B100 fuel when tested at full load engine condition.

7. DEE is a potential additive to biodiesel which not only alters the physical and chemical properties of biodiesel close to diesel fuel, but also improves in terms of reduced BSFC, CO, HC emissions and higher BTE.

\section{Scope for Future Work}

This research work can be extended to know the effects of dispersion of various nano additives (metal, metal oxide, magnetic nano-fluid, nano organic, carbon nanotubes and different combinations) on the performance and emission characteristics of various fuels. The results of nano additives can be compared with the diethyl ether additive.

\section{ACKNOWLEDGEMENT}

The authors are pleased to acknowledge that the work reported in this paper was supported by Visveswaraya Technological University, Belagavi, related to Competitive Research Fund (Reference: VTU/TEQIP 3/2019/321) under TEQIP Program.

\section{REFERENCES}

Agarwal, A. K. (2005). Experimental investigations of the effect of biodiesel utilization on lubricating oil tribology in diesel engines. Proceedings of the Institution of Mechanical Engineers, Part D: Journal of Automobile Engineering, 219(5), $703-713$. https://doi.org/10.1243/095440705X11239

Agarwal, A. K., Bijwe, J. and Das, L. M. (2003). Effect of biodiesel utilization of wear of vital parts in compression ignition engine. Journal of Engineering for Gas Turbines and Power, 125(2), 604-611. https://doi.org/10.1115/1.1454114

Ali, O. M., Mamat, R., Masjuki, H. H. and Abdullah, A. A. (2016). Analysis of blended fuel properties and cycle-to-cycle variation in a diesel engine with a diethyl ether additive. Energy conversion and management, 108, $511-519$. https://doi.org/10.1016/j.enconman.2015.11.035

Arul Gnana Dhas, A., Devarajan, Y. and Nagappan, B. (2018). Analysis of emission reduction in ethyne-biodiesel-aspirated diesel engine. International Journal of Green Energy, 15(7), 436-440. https://doi.org/10.1080/15435075.2018.1473774

Banapurmath, N. R., Tewari, P. G. and Hosmath, R. S. (2008). Performance and emission characteristics of a DI compression ignition engine operated on Honge, Jatropha and sesame oil methyl esters. Renewable Energy, 33(9), $1982-1988$. https://doi.org/10.1016/j.renene.2007.11.012

Barik, D., Murugan, S., Samal, S. and Sivaram, N. M. (2017). Combined effect of compression ratio and diethyl ether (DEE) port injection on performance and emission characteristics of a DI diesel engine fueled with upgraded biogas (UBG)-biodiesel dual fuel. Fuel, 209, 339-349. https://doi.org/10.1016/j.fuel.2017.08.015

Bora, D. K. and Baruah, D. C. (2012). Assessment of tree seed oil biodiesel: A comparative review based on biodiesel of a locally available tree seed. Renewable and Sustainable Energy Reviews, 16(3), 1616-1629. https://doi.org/10.1016/j.rser.2011.11.033 
Chakraborty, M., Baruah, D. C. and Konwer, D. (2009). Investigation of terminalia (Terminalia belerica Robx.) seed oil as prospective biodiesel source for North-East India. Fuel Processing Technology, 90(12), $1435-1441$. https://doi.org/10.1016/j.fuproc.2009.06.023

Chourasia, S., Patel, P. D., Lakdawala, A. and Patel, R. N. (2018). Study on tribological behavior of biodiesel-Diethyl ether (B20A4) blend for long run test on compression ignition engine. Fuel, 230, 64-77. https://doi.org/10.1016/j.fuel.2018.05.055

Das, D., Kumar, A. and Yadav, A. (2018). Evaluation of performance, emission and combustion characteristics of a $\mathrm{Cl}$ engine fueled with karanja biodiesel and diethyl ether blends. Biofuels, 9(1), 89-94. https://doi.org/10.1080/17597269.2016.1257318

Devaraj, A., Yuvarajan, D. and Vinoth Kanna, I. (2018). Study on the Outcome of a Cetane Improver on the Emission Characteristics of a Diesel Engine. International Journal of Ambient Energy, 1-4. https://doi.org/10.1080/01430750.2018.1557546

Devaraj, J., Robinson, Y. and Ganapathi, P. (2015). Experimental investigation of performance, emission and combustion characteristics of waste plastic pyrolysis oil blended with diethyl ether used as fuel for diesel engine. Energy, 85, 304-309. https://doi.org/10.1016/j.energy.2015.03.075

Devarajan, Y., Mahalingam, A., Munuswamy, D. B. and Nagappan, B. (2018). Emission and combustion profile study of unmodified research engine propelled with neat biofuels. Environmental Science and Pollution Research, 25(20), $19643-19656$. https://doi.org/10.1007/s11356-018-2137-5

Duke, J. A. (2002). Handbook of medicinal herbs. USA: CRC press. https://doi.org/10.1201/9781420040463

Dwivedi, G. and Sharma, M. P. (2014). Prospects of biodiesel from Pongamia in India. Renewable and Sustainable Energy Reviews, 32, 114-122. https://doi.org/10.1016/j.rser.2014.01.009

Fargione, J. E., Plevin, R. J. and Hill, J. D. (2010). The ecological impact of biofuels. Annual Review of Ecology, Evolution, and Systematics, 41, 351-377. https://doi.org/10.1146/annurev-ecolsys-102209-144720

Fargione, J., Hill, J., Tilman, D., Polasky, S. and Hawthorne, P. (2008). Land clearing and the biofuel carbon debt. Science, 319(5867), 1235-1238. https://doi.org/10.1126/science.1152747

Ghadge, S. V. and Raheman, H. (2005). Biodiesel production from mahua (Madhuca indica) oil having high free fatty acids. Biomass and Bioenergy, 28(6), 601-605. https://doi.org/10.1016/j.biombioe.2004.11.009

Gui, M. M., Lee, K. T. and Bhatia, S. (2008). Feasibility of edible oil vs. non-edible oil vs. waste edible oil as biodiesel feedstock. Energy, 33(11), 1646-1653. https://doi.org/10.1016/j.energy.2008.06.002

Hansen, A. C., Zhang, Q. and Lyne, P. W. (2005). Ethanol-diesel fuel blends--a review. Bioresource technology, 96(3), $277-285$. https://doi.org/10.1016/j.biortech.2004.04.007

Hingu, S. M., Gogate, P. R. and Rathod, V. K. (2010). Synthesis of biodiesel from waste cooking oil using sonochemical reactors. Ultrasonics sonochemistry, 17(5), 827-832. https://doi.org/10.1016/j.ultsonch.2010.02.010

Holman, J.P. (1966). Experimental methods for engineers. McGraw Hill.

Jena, B. S., Jayaprakasha, G. K., Singh, R. P. and Sakariah, K. K. (2002). Chemistry and biochemistry of (-)-hydroxycitric acid from Garcinia. Journal of Agricultural and Food Chemistry, 50(1), 10-22. https://doi.org/10.1021/jf010753k

Kumar, A. and Sharma, S. (2011). Potential non-edible oil resources as biodiesel feedstock: an Indian perspective. Renewable and Sustainable Energy Reviews, 15(4), 1791-1800. https://doi.org/10.1016/j.rser.2010.11.020

Monteiro, M. R., Kugelmeier, C. L., Pinheiro, R. S., Batalha, M. O. and da Silva César, A. (2018). Glycerol from biodiesel production: Technological paths for sustainability. Renewable and Sustainable Energy Reviews, 88, $109-122$. https://doi.org/10.1016/j.rser.2018.02.019

Nanthagopal, K., Ashok, B., Garnepudi, R. S., Tarun, K. R. and Dhinesh, B. (2019). Investigation on diethyl ether as an additive with Calophyllum Inophyllum biodiesel for $\mathrm{Cl}$ engine application. Energy Conversion and Management, 179, $104-113$. https://doi.org/10.1016/j.enconman.2018.10.064

Ong, A. S. H., Kifli, H., Hassan, H. and Chow, C. S. (1990). Palm oil as oleochemical raw materials. In: Proceedings of the 1990 AOCS: World Conference on Oleochemicals into the $21^{\text {st }}$ Century. Thomas, H. Applewhite (ed.), Kuala Lumpur, pp. 82-87.

Orwa, C., Mutua, A., Kindt, R., Jamnadass, R. and Simons, A. (2009). Agroforestree database: a tree species reference \& selection guide version 4.0. World Agroforestry Centre ICRAF, Nairobi, Kenya.

Patel, P. D., Chourasia, S., Shah, N. K., Lakdawala, A. M. and Patel, R. N. (2017). Experimental investigation on reduction of NOx emission of compression ignition engine fuelled with bio-diesel and diethyl ether. International Journal of Global Warming, 11(4), 431-448. https://doi.org/10.1504/IJGW.2017.083669

Ramadhas, A. S., Jayaraj, S. and Muraleedharan, C. (2005). Biodiesel production from high FFA rubber seed oil. Fuel, 84(4), 335-340. https://doi.org/10.1016/j.fuel.2004.09.016

Rathinam, S., Justin Abraham Baby, S. and Devarajan, Y. (2018). Influence of water on exhaust emissions on unmodified diesel engine propelled with biodiesel. Energy Sources, Part A: Recovery, Utilization, and Environmental Effects, 40(21), $2511-2517$. https://doi.org/10.1080/15567036.2018.1503756

Richard, T. L. (2010). Challenges in scaling up biofuels infrastructure. Science, 329(5993), $793-796$. https://doi.org/10.1126/science.1189139

Sahoo, P. K., Das, L. M., Babu, M. K. G. and Naik, S. N. (2007). Biodiesel development from high acid value polanga seed oil and performance evaluation in a Cl engine. Fuel, 86(3), 448-454. https://doi.org/10.1016/j.fuel.2006.07.025 
Sahoo, P. K., Das, L. M., Babu, M. K. G., Arora, P., Singh, V. P., Kumar, N. R. and Varyani, T. S. (2009). Comparative evaluation of performance and emission characteristics of jatropha, karanja and polanga based biodiesel as fuel in a tractor engine. Fuel, 88(9), 1698-1707. https://doi.org/10.1016/j.fuel.2009.02.015

Semwal, R. B., Semwal, D. K., Vermaak, I. and Viljoen, A. (2015). A comprehensive scientific overview of Garcinia cambogia. Fitoterapia, 102, 134-148. https://doi.org/10.1016/j.fitote.2015.02.012

Shao, H. and Chu, L. (2008). Resource evaluation of typical energy plants and possible functional zone planning in China. Biomass and Bioenergy, 32(4), 283-288. https://doi.org/10.1016/j.biombioe.2007.10.001

Somerville, C., Youngs, H., Taylor, C., Davis, S. C. and Long, S. P. (2010). Feedstocks for lignocellulosic biofuels. Science, 329(5993), 790-792. https://doi.org/10.1126/science.1189268

Srihari, S., Thirumalini, S. and Prashanth, K. (2017). An experimental study on the performance and emission characteristics of PCCI-DI engine fuelled with diethyl ether-biodiesel-diesel blends. Renewable Energy, 107, $440-447$. https://doi.org/10.1016/j.renene.2017.01.015

Yang, J., Dai, G., Ma, L., Jia, L., Wu, J. and Wang, X. (2013). Forest-based bioenergy in China: Status, opportunities, and challenges. Renewable and Sustainable Energy Reviews, 18, 478-485. https://doi.org/10.1016/j.rser.2012.10.044 